\title{
STRUKTUR KOMUNITAS VEGETASI MANGROVE DI PESISIR UTARA PULAU MENDANAU DAN PULAU BATU DINDING, KECAMATAN SELAT NASIK KABUPATEN BELITUNG
}

\author{
Mangrove Community Structure at Northern Mendanau Coastal and Batu Dinding Island \\ in Selat Nasik District, Belitung Regency \\ Irma Akhrianti ${ }^{1}$, Franto $^{2}$, Indra Ambalika Syari ${ }^{2}$, Eddy Nurtjahya ${ }^{2}$ \\ ${ }^{1,2}$ Dosen Jurusan Ilmu Kelautan, Fakultas Pertanian, Perikanan dan Biologi UBB \\ ${ }^{2}$ Dosen Jurusan Biologi, Fakultas Pertanian, Perikanan dan Biologi UBB
}

\begin{abstract}
Mendanau Island and Batu Dinding Island are part of small island groups that have a high diversity and density of mangroves. Based on administratively, Mendanau Island is located in the coastal area of Simpang Pesak District, Belitung Regency, which consist of one large island (Mendanau Island) and 1 small island (Batu Dinding Island). The lack of data about potential, diversity, and community structure of mangroves on the north coast of Mendanau Island and Batu Dinding Island, therefore this research is needed as a database for planning, sustainability management of mangroves at the coastal area and small island. The data of mangrove vegetation was taken by purposive sampling method, with using line transect plot (LTP). Ilustration of sampling design is each line transect have 3 plot / kuadratic transect sized $10 \mathrm{~m} \times 10 \mathrm{~m}$ (capling), $5 \mathrm{~m} \times 5 \mathrm{~m}$ (sapling), $1 \mathrm{~m} \times 1$ $\mathrm{m}$ (seedling). The result showed that there are 12 (twelve) mangrove species were found: jenis $S$. alba, R. apiculata, $R$. stylosa, R. mucronata, B. gymnorhiza, X. granatum, L. littorea. S. hydrophyllacea, S. taccada, H. tiliaceus, Pandanus, dan I. pes-caprae. Mangrove community structure and mangrove condition on the North Coast of Mendanau Island, at several observation stations, was damaged (poor conditions), while the status of the mangrove conditions on Pulau Batu Dinding was still relatively good.
\end{abstract}

Key Words: Mangrove, Mendanau, Batu Dinding, Pulau

\section{PENDAHULUAN}

Kabupaten Belitung adalah kabupaten Induk yang memiliki potensi pulau - pulau kecil dengan potensi pemanfaatan sumberdaya hayati laut yang cukup tinggi, seperti pulau Batu Dinding dan Pesisir Utara Pulau Mendanau. Secara adminstrasi 2 pulau ini termasuk dalam wilayah kecamatan Selat nasik, yang terletak antara $2^{0} 30^{\prime}-$ $4^{0} 15^{\prime}$ Lintang Selatan dan $104^{0} 20^{\prime}-106^{0} 00^{\prime}$ Bujur Timur.

Salah satu sumberdaya laut yang cukup potensial pemanfaatannya di Pesisir Utara Pulau Mendanau dan Pulau Batu Dinding adalah ekosistem mangrove. Secara ekologis mangrove mempunyai beberapa fungsi, antara lain sebagai peredam gelombang mencegah terjadinya abrasi, penahan lumpur, perangkap sedimen, daerah asuhan (nursery grounds), daerah mencari makan (feeding grounds), daerah pemijahan (spawning grounds) serta penghasil kayu untuk bahan konstruksi, kayu bakar, bahan baku arang dan bahan baku kertas (Bengen, 2002).

Menurut Dahuri (2002), secara umum mangrove cukup tahan terhadap berbagai gangguan dan tekanan lingkungan. Namun demikian, permasalahan utama tentang pengaruh atau tekanan terhadap habitat mangrove berasal dari keinginan manusia untuk mengkonversi area hutan mangrove menjadi areal pemukiman, tambak dan pertanian. Selain itu, meningkatnya permintaan terhadap produksi kayu menyebabkan eksploitasi berlebihan terhadap hutan mangrove. Jika eksploitasi berlangsung terus menerus, dapat menyebabkan kematian dan berkurangnya luas hutan mangrove di pesisir utara pulau Mendanau dan Pulau Batu Dinding Kabupaten Belitung Timur.

Pulau Mendanau dan sekitarnya merupakan salah satu kawasan yang terpilih sebagai sentral etalase kelautan Pulau Belitung, dimana kelestarian ekosistem mangrove harus dijaga dan dikelola secara optimal. Informasi lengkap mengenai Status kondisi dan struktur komunitas mangrove di Pesisir Utara Pulau Mendanau dan Pulau Batu Dinding saat ini belum terlaporkan dengan baik dan masih sangat terbatas. Oleh karena itu perlu dilakukan penelitian ini. Penelitian Struktur komunitas mangrove ini merupakan salah satu aspek penting untuk untuk mengetahui kondisi dan peranan penting suatu ekosistem pesisir khususnya komunitas vegetasi mangrove berdasarkan variabel komposisi, keanekaragaman dan struktur komunitas vegetasi mangrove yang dikaitkan dengan parameter lingkungan perairan di wilayah Pesisir Utara Pulau Mendanau dan Pulau Batu Dinding Kabupaten Belitung. Hasil penelitian ini diharapkan menjadi bahan pertimbangan arah kebijakan Pemerintah Daerah Kabupaten Belitung dalam mengelola sumber daya pesisir secara berkesinambungan dengan mengutamakan konservasi dan kelestarian ekosistem mangrove sebagai perwujudan pengembangan etalase kelautan.

\section{METODE}

\section{Waktu dan Tempat Penelitian}

Penelitian ini dilakukan di wilayah pesisir utara Pulau Mendanau dan Pulau Batu Dinding, Kabupaten Belitung. Studi pendahuluan dilakukan selama \pm 1 tahun yaitu di Tahun 2010 kemudian dilakukan update data kondisi umum Pulau Mendanau dan disekitarnya pada tahun 2015.

\section{Alat dan Bahan \\ Alat dan bahan yang digunakan dalam penelitian ini, yaitu Global Positioning System (GPS), hand refraktometer, kamera, kertas label, roll meter, kompas, tali rafia, gunting atau pisau, kantong plastik yang porous beserta kertas koran, alkohol, multi-parameter analyser,}


data sheets pengamatan, alat tulis kerja (ATK), dan buku identifikasi mangrove.

Metode Penelitian.

\section{Penentuan Stasiun Pengamatan}

- Stasiun pengamatan ditentukan berdasarkan purposive sampling method, yakni penentuan lokasi sampling yang dipilih harus berdasarkan keterwakilan area contoh, serta merujuk pada beberapa pertimbangan dan kemampuan peneliti dalam menjangkau stasiun pengamatan. Letak dan posisi geografis stasiun penelitian tersaji pada Gambar 1 dan Tabel 1.

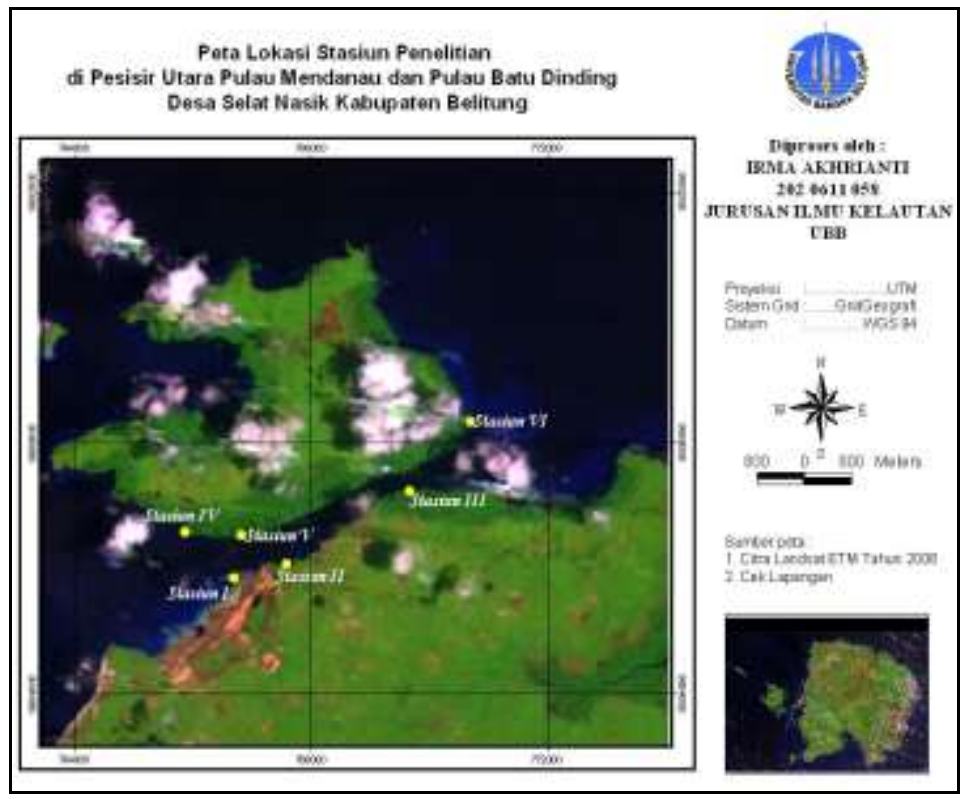

Gambar 1. Lokasi enam (6) stasiun yang diamati

Tabel 1. Posisi Geografis Stasiun Penelitian

\begin{tabular}{lll}
\hline No & Lokasi & Letak Geografis \\
\hline 1 & Pasir Panjang & $02^{\circ} 50^{\prime} 17.4^{\prime \prime} \mathrm{LS}-107^{\circ} 24^{\prime} 01.0^{\prime \prime} \mathrm{BT}$ \\
2 & Kampung Pasir & $02^{\circ} 500^{\prime} 13.7^{\prime \prime} \mathrm{LS}-107^{\circ} 24^{\prime} 15.7^{\prime \prime} \mathrm{BT}$ \\
3 & Kampung Tomo' & $02^{\circ} 49^{\prime} 41.6^{\prime \prime} \mathrm{LS}-107^{\circ} 25^{\prime} 13.9^{\prime \prime} \mathrm{BT}$ \\
4 & Tanjung Lumpur & $0^{\circ} 49^{\prime} 57.0^{\prime \prime} \mathrm{LS}-107^{\circ} 23^{\prime} 27.7^{\prime \prime} \mathrm{BT}$ \\
5 & Kampung Seberang & $02^{\circ} 50^{\prime} 0.93^{\prime \prime} \mathrm{LS}-107^{\circ} 24^{\prime} 13.3{ }^{\prime \prime} \mathrm{BT}$ \\
6 & Pangkalan Bakau & $02^{\circ} 49^{\prime} 03.0^{\prime \prime} \mathrm{LS}-107^{\circ} 26^{\prime} 07.2^{\prime \prime} \mathrm{BT}$ \\
\hline
\end{tabular}

Jenis Data yang Dikumpulkan. Jenis data yang dikumpulkan terdiri dari 2 macam, yaitu data primer dan data sekunder. Data primer yang dikumpulkan meliputi 11 (sebelas) tahapan kegiatan, yaitu: a) identifikasi jenis-jenis mangrove yang ditemukan (komposisi), b) kerapatan jenis, c) kerapatan jenis relatif, d) frekuensi jenis, e) frekuensi jenis relatif, f) penutupan jenis, g) penutupan jenis relatif, h) indeks nilai penting, i) keanekaragaman, keseragaman, dan dominansi serta j) pengukuran parameter lingkungan. Data sekunder yang dikumpulkan dalam penelitian ini adalah informasi terkait kondisi umum Pulau Mendanau dan Pulau Batu Dinding, khususnya dikawasan ekosistem mangrove serta data penelitian hutan mangrove yang pernah dilakukan.

Metode Pengambilan Data dan Penentuan Status
Kondisi Mangrove
- Pengamatan terhadap struktur dan komposisi spesiesspesies tumbuhan dilakukan dengan metode transek garis dan petak contoh (Line Transect Plot- LTP) Pada setiap stasiun pengamatan, bentangkan transek garis dari laut ke arah darat (tegak lurus garis pantai sepanjang zonasi hutan mangrove) $\pm 100 \mathrm{~m}$ di zona intertidal, lalu letakkan 3 petak contoh berukuran $10 \mathrm{~m}$ $\mathrm{x} 10 \mathrm{~m}$ secara sistematik pada setiap line transek dengan jarak antar plot $30 \mathrm{~m}$ (Bengen, 2002).

- Pada setiap petak contoh yang telah ditentukan, dideterminasi setiap jenis tumbuhan mangrove yang ada. Selain itu lakukan pengukuran jumlah individu setiap jenis dan lingkar diameter batang pohon. Pengukuran lingkar diameter batang dilakukan setinggi dada (DBH = Diameter Breast High) atau sekitar 1,3 m dari permukaan tanah, dengan nilai $\mathrm{DBH}>4 \mathrm{~cm}$. Bagi pohon yang mempunyai akar banir dan akar tunjang, pengukuran dilakukan tepat di atas banir dan pangkal akar tunjang. Peletakan transek kuadrat (plot) pengamatan mangrove dilakukan secara menyilang dimulai dari kiri, kanan dan kiri kembali.

- Identifikasi spesies vegetasi dilakukan secara in-situ di lapangan dengan mengacu pada Kitamura et al. (1997), Noor et al. (1999) dan Tomlinson (1986). Apabila belum diketahui nama spesies tumbuhan mangrove yang ditemukan, potonglah bagian ranting lengkap dengan daunnya, dan bila mungkin bunga dan buahnya.

- Pada setiap petak contoh (plot) ambil sampel substrat, kemudian amati secara visual dan catat tipe substrat (lumpur, lempung, pasir, dan sebagainya). Kemudian Melakukan Pengukuran parameter lingkungan yang mempengaruhi keberlangsungan hidup vegetasi mangrove, baik secara insitu dan skala laboratorium.

- Catat semua titik letak koordinat dari setiap stasiun pengamatan menggunakan GPS dan kondisi lingkungan sekitarnya.

- Penentuan status kondisi mangrove di lokasi penelitian mengacu pada Keputusan Menteri Lingkungan Hidup No. 201 Tahun 2004, dengan kriteria sebagai berikut:

Tabel 2. Kriteria Penentuan Status Kondisi Ekosistem Mangrove

\begin{tabular}{clcc}
\hline \multicolumn{2}{c}{ Kriteria } & $\begin{array}{c}\text { Penutupan } \\
(\%)\end{array}$ & $\begin{array}{c}\text { Kerapatan } \\
(\text { pohon/ha) }\end{array}$ \\
\hline Baik & $\begin{array}{l}\text { Sangat } \\
\text { Padat }\end{array}$ & $\geq 75$ & $\geq 1500$ \\
& Sedang & $\geq 50-<75$ & $\geq 1000-<$ \\
& & 1500 \\
\hline Rusak & Jarang & $<50$ & $<1000$ \\
\hline
\end{tabular}

\section{Analisis Data Vegetasi Mangrove}

a. Kerapatan jenis (Ki)

Kerapatan jenis (Ki) adalah jumlah individu jenis $\mathrm{i}$ dalam suatu unit area. Kerapatan jenis dihitung berdasarkan rumus sebagai berikut :

$$
\operatorname{Di}=\frac{n i}{A}
$$

dimana:

Di $=$ kerapatan jenis $\mathrm{i}$ 
ni $\quad=$ jumlah total tegakan individu dari jenis $\mathrm{i}$

A = luas area total pengambilan contoh (luas total petak contoh.

\section{b. Kerapatan relatif jenis (RDi)}

Kerapatan relatif jenis (RDi) adalah perbandingan antara jumlah individu jenis $\mathrm{i}$ (ni) dengan total tegakan seluruh jenis $\left(\sum \mathrm{n}\right)$ :

$$
\mathrm{RDi}=\left(\frac{\mathrm{ni}}{\Sigma \mathrm{n}}\right) \times 100 \%
$$

dimana :

$$
\begin{array}{ll}
\mathrm{RDi} & =\text { kerapatan relatif } \\
\mathrm{ni} & =\text { jumlah total suatu jenis } \\
\sum \mathrm{n} & =\text { kerapatan seluruh jenis }
\end{array}
$$

\section{c. Frekuensi Jenis (Fi)}

Frekuensi jenis ( $\mathrm{Fi})$, yaitu peluang ditemukannya suatu jenis ke-i didalam semua petak contoh dibandingkan dengan jumlah total petak contoh yang dibuat :

$$
\mathrm{Fi}=\frac{p i}{\sum p}
$$

dimana :

$\mathrm{Fi} \quad=$ Frekuensi jenis $\mathrm{i}$

$\mathrm{Pi} \quad=$ Jumlah petak contoh dimana ditemukan jenis $\mathrm{i}$

$\sum \mathrm{p} \quad=$ Jumlah total petak contoh yang dibuat

\section{d. Frekuensi Relatif Jenis (RFi)}

Frekuensi relative adalah perbandingan antara frekuensi jenis ke-i (Fi) dengan jumlah frekuensi untuk seluruh jenis $\left(\sum \mathrm{F}\right)$ :

$$
\mathrm{RFi}=\left(\frac{F i}{\sum F}\right) x 100 \%
$$

dimana :

$\mathrm{RFi}=$ Frekuensi relative jenis ke-i

$\mathrm{Fi} \quad=$ Frekuensi jenis ke-i

$\sum \mathrm{F} \quad=$ Jumlah frekuensi untuk jenis

\section{e. Penutupan jenis $(\mathbf{C i})$}

Penutup jenis $(\mathrm{Ci})$ adalah luas penutupan jenis i dalam suatu unit area:

$$
\mathrm{Ci}=\frac{\sum B A}{A}
$$

dimana :

$$
\begin{array}{ll}
\mathrm{Ci} & =\text { penutupan jenis atau dominasi jenis } \\
\mathrm{BA} & =\text { basal area }\left(\pi \mathrm{dbh}^{2} / 4\right) \\
\mathrm{A} & =\text { luas total area pengambilan contoh }
\end{array}
$$

\section{f. Basal area}

Basal area adalah daerah yang ditutupi oleh batang pohon mangrove. Basal area juga merupakan asumsi untuk mengetahui besar penutupan kanopi pohon mangrove. Semakin besar basal area maka semakin besar pula penutupan kanopi pohon. Basal area didapatkan dari pengukuran batang pohon secara melintang. Diameter batang tiap spesies tersebut kemudian diubah menjadi basal area dengan menggunakan rumus:

$$
B A=\left\{\frac{\pi D B H^{2}}{4}\right\}
$$

dimana :
$\mathrm{BA}=$ basal area

$\mathrm{DBH}=$ diameter pohon mangrove setinggi dada

$\pi \quad=3,1416$

\section{f. Penutupan Relatif (RCi)}

Penutupan relatif jenis atau dominasi jenis (Ci) adalah perbandingan antara luas daerah penutupan jenis- $i$ dan luas total area penutup untuk seluruh jenis, atau perbandingan antara jumlah total individu jenis-i (Ci) dan jumlah total dominasi seluruh individu $\left(\sum \mathrm{C}\right)$;

$$
\mathrm{RCi}=\left(\frac{C i}{\sum C}\right) x 100 \%
$$

dimana :

$\mathrm{RCi}=$ Penutupan relatif jenis

$\sum \mathrm{Di}=$ Jumlah total dominasi seluruh individu

\section{g. Indeks Nilai Penting (INP)}

Indeks Nilai Penting adalah jumlah nilai Kerapatan Relatif (Di), Frekuensi Relatif (RFi) dan Dominasi Relatif (RCi):

$$
\mathrm{INP}=\mathrm{RDi}+\mathrm{RFi}+\mathrm{RCi}
$$

Nilai penting suatu jenis berkisar antara $0-300$.. Nilai penting ini memberikan gambaran mengenai peranan dari suatu jenis mangrove dalam suatu ekosistem.

\section{h. Indeks Keanekaragaman ( H')}

Indeks keanekaragaman merupakan karakteristik dari suatu komunitas yang menggambarkan tingkat keanekaragaman spesies dari organisme yang terdapat dalam komunitas tersebut (Odum, 1993). Rumusnya adalah:

$$
\mathrm{H}^{\prime}=-\frac{1}{N} \Sigma \mathrm{ni} \log \mathrm{ni}
$$

dimana : H' = indeks Shannon-Wienner

$\mathrm{N}=$ jumlah total spesies

ni $=$ jumlah individu tiap spesies ke-i

Menurut Wilham dan Dorris (1986), klasifikasi indeks keanekaragaman Shannon-Wienner adalah sebagai berikut

$H^{\prime}<1 \quad=$ indeks keanekaragaman rendah

$1 \leq H^{\prime} \leq 3$ = indeks keanekaragaman sedang

$H^{\prime}>3$ = indeks keanekaragaman tinggi

\section{i. Indeks Keseragaman (E)}

Indeks keseragaman merupakan perbandingan antara nilai keanekaragaman dengan logaritma natural dari jumlah spesies (Odum, 1993), rumusnya:

$$
\mathrm{E}=\mathrm{H}^{\prime} / \mathrm{Hmaks}=\mathrm{H}^{\prime} / \log (\mathrm{S})
$$

dimana : H' = indeks Shannon-Wienner

$$
\mathrm{S}=\text { jumlah spesies }
$$

Menurut Krebs (1989), Indeks Keseragaman berkisar antara 0 - 1, dimana
$\mathrm{E}^{\prime}>0,6$
= keseragaman spesies tinggi
$0,4<\mathrm{E}^{\prime}<0,6$
= keseragaman spesies sedang
$\mathrm{E}^{\prime}<0,4$
$=$ keseragaman spesies rendah 


\section{HASIL DAN PEMBAHASAN \\ Kondisi Umum Pulau Mendanau dan Sekitarnya}

Pulau Mendanau terletak di Kecamatan Selat Nasik, Kabupaten Belitung, Provinsi Keputauan Bangka Belitung. Pulau ini mempunyai luas sebesar 12.097,18 Ha dengan jumlah penduduk sekitar 2.335 jiwa. Secara geografis, Pulau Mendanau terletak pada koordinat $107^{\circ} 25^{\prime} 24^{\prime \prime} L S$ 2052'41" BT. Pulau ini memiliki batas wilayah sebagai berikut; disebelah utara berbatasan dengan Pulau Batu Dinding, Sebelah Timur berbatasan dengan Pulau Sebongkok, Sebelah Selatan berbatasan dengan Pulau Naduk dan di sebelah Barat berbatasan dengan Selat Gaspar. Jarak Pulau Mendanau dengan Kota Belitung \pm 3,61 mil laut, yang dapat dicapai dengan perahu motor selama \pm 2 jam. Sarana ini merupakan alat transportasi utama yang digunakan oleh masyarakat pulau untuk beraktivitas ke daerah yang lain.

kondisi Pulau Mendanau secara keseluruhan didominasi oleh tumbuhan mangrove dengan bentuk pantai berbatu dan berpasir berlumpur, dengan kondisi pantai yang berlumpur, sehingga tumbuhan mangrove akan tumbuh dengan subur. Faktor pendukung yang lain adalah terdapatnya Sungai Mapam dan Sungai Rawai di Pulau Mendanau. Pulau Mendanau dibagi menjadi 3 desa yaitu Desa Selat nasik, Desa Petaling, Desa Soak gual.

Lokasi penelitian ini terfokus pada bagian tekecil dari keseluruhan wilayah Pulau Mendanau yaitu di wilayah pesisir utara Pulau Mendanau dan Pulau Batu Dinding yang berada tepat dihadapan pesisir utara Pulau Mendanau. Pulau Batu Dinding merupakan pulau yang letaknya berhadapan dengan Pulau Mendanau pulau Mendanau. Secara administratif, Pulau Batu Dinding termasuk bagian dari wilayah desa Selat nasik yang dikelilingi oleh vegetasi mangrove, Pulau Batu Dinding juga merupakan pulau yang memilki peranan yang sangat penting karena pulau ini telah menjadi benteng pertahanan bagi pesisir utara pulau mendanau dan sekitarnya.

\section{Karakteristik Lingkungan Perairan}

Parameter lingkungan fisika-kimia perairan diukur untuk mengetahui kondisi lingkungan di ekosistem mangrove. Hasil pengukuran parameter fisika kimia perairan selama penelitian di Pesisir Utara Pulau Mendanau dan Pulau Batu Dinding dapat dilihat pada Tabel 3.

Tabel 3. Karakteristik Lingkungan Perairan

\begin{tabular}{lcccccc}
\hline Parameter & \multicolumn{3}{c}{ Pulau Mendanau } & \multicolumn{3}{c}{ Pulau Batu Dinding } \\
\hline \multicolumn{1}{c}{} & $\mathbf{1}$ & $\mathbf{2}$ & $\mathbf{3}$ & $\mathbf{4}$ & $\mathbf{5}$ & $\mathbf{6}$ \\
\hline Fisika & & & & & & \\
Suhu Air $\left({ }^{\circ} \mathrm{C}\right)$ & 33 & 30 & 29 & 33 & 34 & 36 \\
Suhu Udara $\left({ }^{\circ} \mathrm{C}\right)$ & 35 & 31 & 28 & 28 & 30 & 38.5 \\
Kimia & & & & & & \\
pH Perairan & 6 & 7.8 & 7 & 7.5 & 7.5 & 7.8 \\
pH Tanah & 2.5 & 3.5 & 6 & 3.5 & 3 & 4 \\
Salinitas $\left({ }^{\circ} \%\right.$ oо $)$ & 35 & 32 & 33 & 34 & 33 & 33 \\
Tipe Substrat & Pasir & Pasir & Lumpur & $\begin{array}{c}\text { Batu } \\
\text { Karang }\end{array}$ & $\begin{array}{c}\text { Pasir } \\
\text { lumpur }\end{array}$ & $\begin{array}{c}\text { Pasir } \\
\text { Lumpur }\end{array}$ \\
\hline & & & & & &
\end{tabular}

Tabel 3 diatas menunjukkan bahwa nilai suhu, salinitas dan $\mathrm{pH}$ perairan cenderung tinggi, dan $\mathrm{pH}$ tanah tergolong rendah dimana beberapa jenis tumbuhan mangrove (misalnya Sonneratia sp, Rhizophora sp, Bruguiera sp, umumnya dapat beradaptasi pada lingkungan tersebut dengan memiliki daun yang tebal dan kuat yang berfungsi untuk mengatur keseimbangan garam, kemudian pada daun terdapat sel khusus yang berfungsi untuk menyimpan garam serta daunnya juga memilki struktur stomata khusus untuk mengurangi terjadinya penguapan (Bengen, 1999).

Suhu perairan dari seluruh stasiun pengamatan berkisar antara $29-36^{\circ} \mathrm{C}$ dengan nilai rata-rata $32,5^{\circ} \mathrm{C}$, dimana nilai tersebut termasuk nilai yang tinggi untuk suatu suhu perairan. Hal ini di sebabkan juga oleh efektivitas pemanasan massa air secara langsung, namun demikian kisaran ini ternyata masih dalam kisaran suhu rata-rata perairan tropis. Kondisi suhu perairan pada enam stasiun ini diduga cocok bagi produksi daun mangrove dan memicu pertumbuhan yang optimal bagi komunitas mangrove di daerah pesisir. Hal ini didukung oleh pendapat Supriharyono (2000) Suhu yang baik untuk kehidupan mangrove tidak kurang dari $20^{\circ} \mathrm{C}$, sedangkan kisaran musiman suhu tidak melebihi $5^{\circ} \mathrm{C}$, suhu yang tinggi $\left(<40^{\circ} \mathrm{C}\right)$ cenderung tidak mempengaruhi pertumbuhan dan kesuburan mangrove.

Suhu udara dari keseluruhan stasiun yang diamati berkisar $28-38,5^{\circ} \mathrm{C}$, adanya perbedaan rentang nilai $\pm 10^{\circ} \mathrm{C}$, diduga disebabkan karena adanya variasi waktu pengukuran dan kerapatan kanopi mangrove sehingga mempengaruhi suhu lokal pada saat melakukan pengukuran. Setyawan (2008) menambahkan bahwa sinar matahari, suhu dan kelembaban udara sangat berpengaruh terhadap kenaekaragaman spesies di suatu habitat, adanya perbedaan suhu perairan tergantung pada limit waktu pemanasan massa air oleh radiasi sinar matahari selain itu bisa juga dipengaruhi oleh posisi matahari, letak geografis, musim, serta kondisi cuaca dan awan pada saat melakukan pengukuran.

pH perairan pada seluruh lokasi penelitian berkisar antara 6 - 7,8. Menurut Effendi (2003) sebagaian besar biota akuatik sensitif terhadap perubahan $\mathrm{pH}$ dan menyukai nilai $\mathrm{pH}$ sekitar 7 - 8,5. Nilai $\mathrm{pH}$ perairan tertinggi terdapat pada Stasiun 2 dan Stasiun 4 yaitu sebesar 7,8 dan nilai $\mathrm{pH}$ terendah terdapat pada Stasiun I sebesar 6. Perbedaan nilai $\mathrm{pH}$ perairan yang terukur diduga dipengaruhi oleh letak stasiun pengamatan, dimana Stasiun I terletak di daerah lahan terbuka pasca penambangan pasir kuarsa yang lokasinya berdekatan dengan perairan tawar sehingga mendapatkan pengaruh masukan bahan organik, selain itu diduga karena adanya proses pengadukan oleh arus antara $\mathrm{pH}$ perairan dengan kandungan $\mathrm{pH}$ tanah yang rendah, menyebabkan nilai $\mathrm{pH}$ yang terukur lebih rendah dari $\mathrm{pH}$ netral artinya kondisi perairan pada stasiun I bersifat asam.

pH tanah Hasil pengukuran $\mathrm{pH}$ tanah di lokasi penelitian berkisar 2.5 - 6. Menurut Arief (2003) secara umum $\mathrm{pH}$ tanah pada ekosistem mangrove tidak banyak berbeda, yaitu antara 4,6 - 6,5. Nilai $\mathrm{pH}$ tanah terendah terdapat pada Stasiun 1 dan $\mathrm{pH}$ tanah tertinggi ditunjukkan pada Stasiun 4. Kisaran nilai $\mathrm{pH}$ tanah tersebut sangat wajar dengan kondisi tanah mangrove di daerah tropis 
khususnya di wilayah Bangka Belitung yang cenderung asam. Menurut pendapat Setyawan (2002), tanah mangrove umumnya bersifat netral hingga sedikit asam karena aktivitas bakteri pereduksi belerang dan adanya sedimentasi tanah lempung yang asam, aktivitas bakteri pereduksi belerang ditunjukkan oleh tanah gelap, asam dan berbau busuk.

Salinitas merupakan faktor utama yang paling menetukan pertumbuhan, zonasi dan penyebaran mangrove di suatu daerah (Bengen, 2002). Kisaran nilai salinitas di Perairan Pesisir Utara Pulau Mendanau dan Pulau Batu Dinding berkisar antara $32-35 \%$. Menurut Dahuri (2003) nilai salinitas optimum untuk tumbuhan mangrove adalah $35 \%$, artinya kisaran nilai berdasarkan hasil pengamatan berada pada kisaran normal /ideal bagi kelangsungan hidup ekosistem mangrove. Hal ini juga didukung oleh pendapat Bengen (1999), yang menyatakan bahwa mangrove dapat hidup pada perairan bersainitas payau (20-22\%o) hingga asin (mencapai 38\%o). Menurut Dahuri et al. (2008) perbedaan nilai salinitas perairan disebabkan karena adanya perubahan penggunaan lahan di darat yang dapat mengakibatkan terjadinya modifikasi masukan air tawar, masukan nutrien dan sedimen sehingga akan mengubah kadar garam yang ada. Nilai salinitas stasiun 3, 4, dan 6 cenderung homogen, yaitu $33 \%$ Menurut Widodo (2004), pada musim timur (JuniOktober), wilayah perairan laut Pulau Belitung dipengaruhi oleh arus dari timur, dimana salinitas perairan bersifat polihaline $(32-34 \%)$.

Tipe substrat pada masing-masing stasiun pengamatan cenderung bervariasi, yaitu pasir, lumpur, pasir berlumpur serta pecahan karang. Adanya perbedaan ini diduga disebabkan karena adanya perbedaan karakteristik habitat dan kondisi oseanografi yang cenderung fluktuatif. Dahuri (2008) menyatakan bahwa ada beberapa faktor yang menentukan kelangsungan hidup dan pertumbuhan mangrove yaitu suhu, pasokan nutrien, kestabilan substrat, suplai air tawar dan salinitas. Tabel 3, menunjukkan bahwa stasiun 3, 5, 6 cenderung homogen yaitu, dominan fraksi lumpur dengan jenis dominan yang tercatat adalah dari famili Rhizophoraceae. Menurut Noor et al. (1999), Rhizophora apiculata dapat tumbuh subur pada habitat yang substratnya terkandung lumpur dan kaya akan bahan organik, sedangkan tipe substrat pada stasiun 1, dan 2 yaitu pasir, dan tipe substrat pada stasiun 4 adalah pecahan karang. Jenis mangrove yang ditemukan merupakan spesies yang toleran terhadap substrat pasir, hal ini sesuai dengan apa yang dikemukakan oleh Noor et al., (1999) bahwa jenis Rhizophora stylosa tumbuh pada habitat yang beragam di daerah pasang surut, lumpur, pasir dan batu. Menyukai pematang sungai pasang surut, tetapi juga sebagai jenis pionir di lingkungan pesisir atau pada bagian daratan dari mangrove. Satu jenis relung khas yang bisa ditempatinya adalah tepian mangrove pada pulau/substrat karang.

\section{Komposisi dan Eksistensi Jenis Mangrove}

Berdasarkan hasil identifikasi dilapangan, ditemukan 8 jenis mangrove sejati dari 5 famili yang teridentifikasi di keseluruhan stasiun pengamatan, meliputi Rhizophoraceae ( $R$. apiculata, $R$. mucronata, $R$. stylosa, $B$. gymnorrhiza), Sonneratiaceae (S. alba), Meliaceae $(X$. granatum), Combretaceae (L. littorea), Rubiaceae ( $S$. hydrophyllaceae). Disamping itu ada juga ditemukan 4 jenis mangrove asosiasi dari 4 famili, yaitu Malvaceae $(H$. tiliaceus), Convolvulaceae (I. pescaprae), Pandanaceae (Pandanus sp.), Goodeniaceae (S. tacada).

Tabel 4. Komposisi Jenis Mangrove

\begin{tabular}{|c|c|c|c|c|c|c|c|}
\hline \multirow{2}{*}{ No } & \multirow{2}{*}{ Jenis Mangrove } & \multicolumn{6}{|c|}{ Stasiun } \\
\hline & & 1 & 2 & 3 & 4 & 5 & 6 \\
\hline & Mangrove Sejati & & & & & & \\
\hline 1 & Bruguiera gymnorrhiza $(\mathrm{L}) \mathrm{Lam}$ & + & + & - & - & - & - \\
\hline 2 & Rhizophora apiculata Blume & + & - & + & + & + & + \\
\hline 3 & Rhizophora mucronata Lamk & + & - & + & - & + & + \\
\hline 4 & Rhizophora stylosa Griff & + & - & + & - & - & + \\
\hline 5 & Sonneratia alba ( J). Sim & + & - & - & + & + & + \\
\hline 6 & Xylocarpus granatum Koen & + & + & - & - & - & - \\
\hline 7 & Lumnitzera littorea (Jack) Voight & - & + & - & - & - & - \\
\hline 8 & $\begin{array}{l}\text { Scyphiphora hydrophyllacea } \\
\text { Gaertn.F }\end{array}$ & - & - & + & - & - & - \\
\hline & Mangrove Asosiasi & & & & & & \\
\hline 1 & Hibiscus tiliaceus $\mathrm{L}$ & + & - & - & - & - & - \\
\hline 2 & Ipomoea pes-caprae $(\mathrm{L})$ Sweet & + & - & - & - & - & - \\
\hline 3 & Pandanus sp Parkinson & + & - & - & - & - & - \\
\hline 4 & Scaevola taccada (Gaertn.) Roxb & + & + & - & - & - & - \\
\hline
\end{tabular}

Keterangan:

$(+)$ : Ada ditemukan jenis mangrove ke-i

( - ) : Tidak ditemukan jenis mangrove ke-1

\section{Ilustrasi Struktur Komunitas Vegetasi dan Gambaran Kondisi Ekosistem Mangrove di Lokasi Penelitian}

\section{a. Kondisi Mangrove Pada Stasiun 1}

Stasiun I terletak di daerah Pasir Panjang dengan hamparan pasir putih di sepanjang pesisir Utara Pulau Mendanau. Lokasi ini merupakan lokasi yang terbuka karena letaknya yang berdekatan dan berhadapan dengan laut lepas sehingga pengaruh gelombang pada Stasiun I relatif lebih besar. Mangrove tumbuh sangat tipis pada Stasiun ini, pada beberapa titik pengamatan terlihat kawasan mangrove yang hilang, hal ini diduga karena wiilayah sekitar Stasiun I merupakan daerah pasca penambangan pasir kuarsa di laut yang telah berdampak terjadinya sedimentasi. Gambaran kondisi mangrove pada Stasiun I disajikan pada Gambar 2 berikut ini.

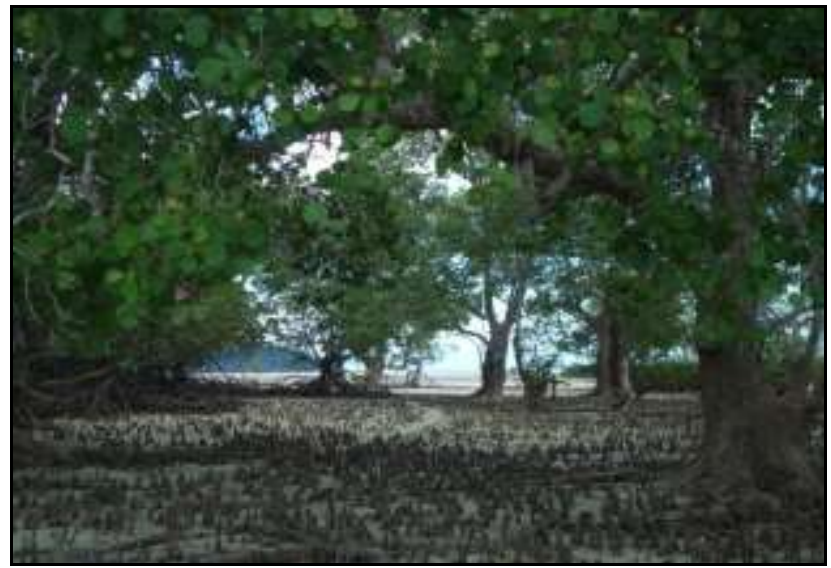

Gambar 2. Kondisi Mangrove Pada Stasiun 1

Jenis- jenis mangrove yang tumbuh lebih banyak pada Stasiun 1 untuk kategori semai, belta, dan pohon cenderung berbeda. Jenis mangrove $S$. alba, $R$. stylosa, dan B. gymnorrhiza ditemukan sebagai vegetasi yang tumbuh lebih banyak pada Stasiun 1 untuk kategori pohon dengan indeks nilai penting dan nilai kerapatan berturut-turut 
sebesar $173.02 \%$ (140 ind/ha), 46.60\% (40 ind/ha), $32.04 \%$ (40 ind/ha). Pada stadium pertumbuhan belta ditemukan jenis $H$. tiliaceus, $R$. stylosa dan $X$. granatum dengan nilai penting dan kerapatan secara berturut-turut sebesar $78.36 \%$ (480 ind/ha), 37.48\% (240 ind/ha), dan $11,17 \%$ (80 ind/ha). Semai yang ditemukan pada Stasiun I lebih bervariasi dimana terdapat 3 jenis yang paling mendominasi yaitu dari jenis $B$. gymnorrhiza dengan INP sebesar 39.29\% (2.000 ind/ha), R. apiculata dan Pandanus sp. dengan nilai penting dan kerapatan yang sama yaitu sebesar $33.04 \%$ (1.500 ind/ha), sedangkan indeks nilai penting dan kerapatan terendah pada kategori semai yakni jenis S. alba sebesar 20.54\% (500 ind/ha). Kerapatan tegakan pohon secara keseluruhan berjumlah 260 ind/ha, kemudian total kerapatan tegakan belta berjumlah 480 ind/ha dan total kerapatan semai sebesar 8.000 ind/ha.

Total keseluruhan kerapatan pohon pada Stasiun 1 lebih rendah dibandingkan dengan total kerapatan belta dan semai. Berdasarkan informasi masyarakat setempat, kondisi ini diduga disebabkan oleh terjadinya kematian mangrove pada tingkat pohon, baik karena kegiatan eksploitasi beberapa jenis hutan mangrove (Rhizophora sp) yang berlebihan maupun akibat dampak pencemaran pesisir dan laut oleh kegiatan pasca penambangan pasir kuarsa yang dilakukan pada tahun 2002 yang menyebabkan tingginya sedimentasi. Setyawan (2005) menambahkan secara tradisional masyarakat lokal menggunakan kayu mangrove untuk memasak, membangun rumah dan perahu secara lestari, namun bertambahnya penduduk menyebabkan penggunaan sumberdaya alam (mangrove) secara lestari sulit dipertahankan, akan tetapi tingginya nilai total kerapatan belta dan semai bila dibandingkan dengan total kerapatan pohon pada Stasiun 1 merupakan indikator bahwa terjadi regenerasi yang baik untuk menggantikan mangrove yang berusia tua dimana sebagian besar komunitas mangrove telah mengalami kematian sehingga dapat diramalkan bahwa kondisi mangrove pada masa yang akan datang relatif stabil apalagi didukung oleh parameter lingkungan mangrove yang tidak berubah secara dinamis.

Jenis-jenis mangrove yang ditemukan pada Stasiun 1 untuk stadium pertumbuhan semai, belta, dan pohon cenderung berbeda, kondisi ini diduga terkait pada faktor substrat dan parameter fisika kimia yang diukur pada lokasi penelitian, tipe substrat pada Stasiun 1 berdasarkan pengamatan secara visual yaitu berpasir. Jenis $S$. alba kategori pohon tumbuh dominan di bagian terdepan zonasi mangrove yang berhadapan langsung dengan laut, hal ini mengindikasikan bahwa jenis mangrove $S$. alba memiliki peranan yang sangat penting dalam menyusun struktur vegetasi mangrove di daerah tersebut didukung oleh faktor lingkungan yang sesuai untuk kelangsungan hidup $S$. alba. Semai jenis $S$. alba ditemukan dalam jumlah populasi yang sedikit pada Stasiun 1 hal ini diduga disebabkan oleh letak $S$. alba yang paling dekat dengan laut memungkinkan sulitnya melakukan regenerasi pada tingkat semai karena hempasan gelombang yang terlalu tinggi, Tomlinson (1986) mengatakan daerah yang paling dekat dengan laut sering ditumbuhi jenis $S$. alba dan Avicennia alba Blume. Berbeda halnya dengan kategori belta yang didominasi oleh tumbuhan asosiasi jenis Hibiscus tiliaceus, kondisi ini menandakan bahwa mangrove tumbuh tipis pada Stasiun I, karena pada titik ini sudah mencapai wilayah daratan. Bengen (2002) menyatakan Hibiscus tiliaceus tumbuh di daratan dengan frekuensi penggenangan massa air secara musiman dimana salinitas berkisar antara $0-10 \%$.

Secara umum, saat ini kondisi hutan mangrove pada Stasiun 1 dan sekitarnya sudah mulai terganggu dan dapat dikatakan berada dalam kondisi yang buruk serta dapat dikelompokkan ke dalam tipe mangrove yang memiliki kerapatan jarang, hal ini berdasarkan dari penambahan nilai kerapatan kategori pohon dan kategori belta (sapling) sebesar 740 ind/ha, dimana hasil perhitungan nilai kerapatan tersebut berjumlah $<1.000$ pohon/ha. Penilaian kriteria ini adalah berdasarkan SK Menteri Lingkungan Hidup No. 201 tahun 2004, yaitu bahwa hutan mangrove dengan kerapatan sebesar $\geq 1.500$ pohon/ha, dengan penutupan tajuk (canopy) sebesar $>75 \%$ adalah termasuk dalam kondisi sangat baik, sedangkan kerapatan antara 1.000-1.500 pohon/ha, dengan penutupan tajuk antara 50-75\% adalah termasuk kondisi sedang, serta lebih kecil dari 1.000 pohon/ha, dengan penutupan tajuk kurang dari $50 \%$ adalah jarang dan dalam kondisi tidak baik (buruk). Kerusakan ekosistem mangrove pada Stasiun 1 lebih disebabkan oleh adanya tekanan ekologis yang diduga semakin tinggi akibat dampak dari kegiatan manusia baik secara langsung maupun secara tidak langsung oleh karena itu perlu dilakukan kegiatan konservasi pada daerah sekitar Stasiun 1.

\section{b. Kondisi Mangrove Pada Stasiun 2}

Lokasi Stasiun 2 terletak di Kampung Pasir tepatnya di wilayah Pesisir Utara Pulau Mendanau dengan kondisi mangrove yang sudah terganggu diduga akibat adanya kegiatan penebangan dan konversi lahan mangrove menjadi tempat pencucian bauksit, sehingga berdampak merubah zonasi mangrove yang ada. Mangrove tumbuh tipis dan tersebar secara tidak merata pada Stasiun 2. Gambaran kondisi mangrove pada Stasiun 2 disajikan pada Gambar 3 berikut ini.

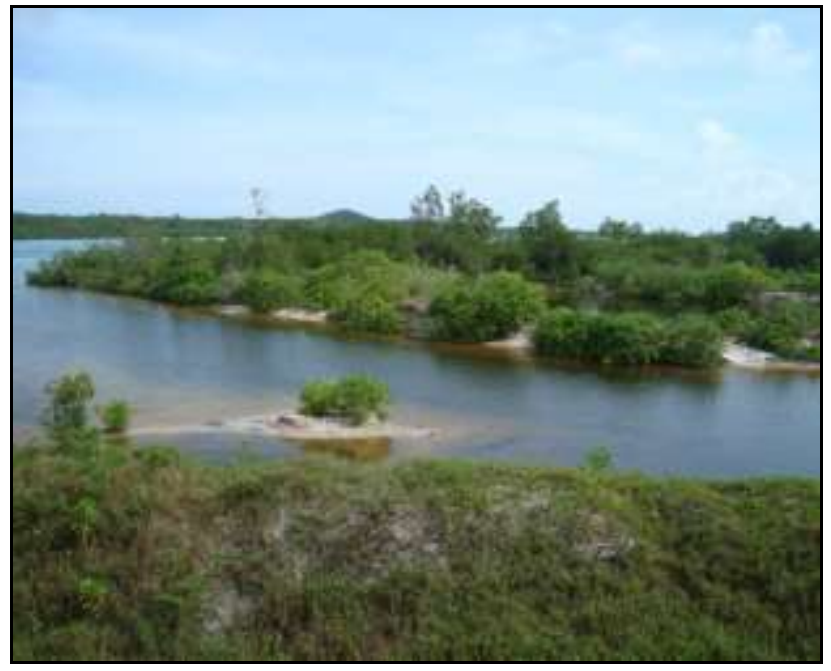

Gambar 3. Kondisi Mangrove Pada Stasiun 2

Jenis - jenis mangrove yang tumbuh lebih banyak pada Stasiun 2 untuk kategori semai, belta, dan pohon cenderung berbeda. Jenis $X$. granatum pada kategori pohon memilki jumlah populasi yang relatif lebih banyak dibandingkan dengan jenis L. littorea. Jenis X. granatum 
memilki indeks nilai penting sebesar $154.2 \%$ (20 ind/ha), sementara $L$. littorea memililki indeks nilai penting sebesar $145.8 \%$ (20 ind/ha). Jenis mangrove $S$. taccada dan B. gymnorrhiza ditemukan sebagai vegetasi yang tumbuh dominan pada kategori belta dengan indeks nilai penting dan kerapatan secara berturut-turut sebesar $132.21 \%$ (400 ind/ha), 67.79\% (320 ind/ha). Pada stadium pertumbuhan semai hanya ditemukan 1 jenis mangrove yang relatif lebih banyak jumlah populasinya pada stasiun 2, yaitu dari jenis mangrove $B$. gymnorrhiza dengan nilai penting sebesar 200\% (500 ind/ha). Kerapatan tegakan pohon secara keseluruhan pada Stasiun 2 berjumlah 40 ind/ha, kemudian total kerapatan tegakan belta berjumlah $720 \mathrm{ind} /$ ha dan total kerapatan semai sebesar $500 \mathrm{ind} / \mathrm{ha}$.

Pohon $X$. granatum memiliki indeks nilai penting tertinggi pada Stasiun 2, artinya jenis mangrove ini memilki peranan yang sangat penting dalam menyusun struktur vegetasi mangrove di daerah tersebut. Noor (1999) menyatakan bahwa jenis $X$. granatum merupakan tumbuhan mangrove minor yang umumnya tumbuh pada arah daratan, jauh dari fluktuasi genangan pasang surut. Jenis mangrove ini diduga lebih mampu bertahan hidup dan juga mampu beradaptasi pada kawasan mangrove yang mengalami kerusakan akibat adanya konversi lahan mangrove. Dampak dari kegiatan manusia ini ternyata telah merubah zonasi mangrove pada Stasiun 2 dan mengakibatkan ketebalan mangrove semakin tipis dan semakin berkurangnya komposisi dan keanekaragaman jenis mangrove di daerah tersebut karena daya dukung lingkungan yang semakin menurun. Menurut Dahuri (2008), Konversi Lahan Mangrove merupakan dampak dari kegiatan manusia yang memberikan sumbangan terbesar bagi kerusakan ekosistem mangrove di wilayah pesisir.

Pada kategori semai dan belta ditemukan jenis yang sama tumbuh dominan yaitu jenis $B$. gymnorhiza. Tumbuhnya jenis mangrove $B$. gymnorrhiza ini merupakan indikator wilayah yang sudah masuk kedaratan. Tabel 4.3 menunjukkan INP tertinggi kategori semai yaitu jenis $B$. gymnorrhiza sebesar 200\% terdapat pada Stasiun 2 Hal ini dikarenakan pada lokasi tersebut hanya ditemukan 1 jenis B. gymnorrhiza yang bisa tumbuh sementara jenis-jenis lainnya tidak bisa tumbuh akibat kondisi lingkungan yang kurang mendukung oleh karena itu nilai INP mutlak bernilai $200 \%$.

Nilai total kerapatan tegakan pohon lebih rendah dibandingkan dengan kerapatan tegakan semai dan belta. Kondisi ini disebabkan karena ada beberapa jenis mangrove tertentu khususnya populasi Rhizophora sp menghilang/tidak ditemukan lagi di daerah tersebut akibat adanya penebangan pohon mangrove untuk pembukaan lahan baru. sehingga jenis mangrove tersebut tidak memilki peluang besar untuk melakukan regenerasi kembali dengan baik. Jika melihat nilai kerapatan untuk tingkat semai, kondisi mangrove pada Stasiun 2 dimasa yang akan datang, diramalkan hanya memilki tingkat kerapatan mangrove jarang dan berada dalam kondisi yang cukup mengkhawatirkan (buruk) jika tidak dilakukan upaya konservasi dan rehabilitasi pada Stasiun 2.

\section{c. Kondisi Mangrove Pada Stasiun 3}

Stasiun 3 terletak di Kampung Tomo tepatnya tidak jauh berdekatan dengan dermaga kapal pertama yang dibangun di Pesisir Utara Pulau Mendanau. Lokasi mangrove yang berada di sekitar Kampung Tomo terlindung dari hempasan ombak dan dengan kondisi substrat berlumpur yang bercampur dengan pasir, serta dialiri oleh sungai. Peranan sungai dan terlindungnya daerah tersebut cukup penting bagi keberadaan mangrove. Kondisi mangrove pada Stasiun 3 disajikan pada Gambar 4 berikut ini.

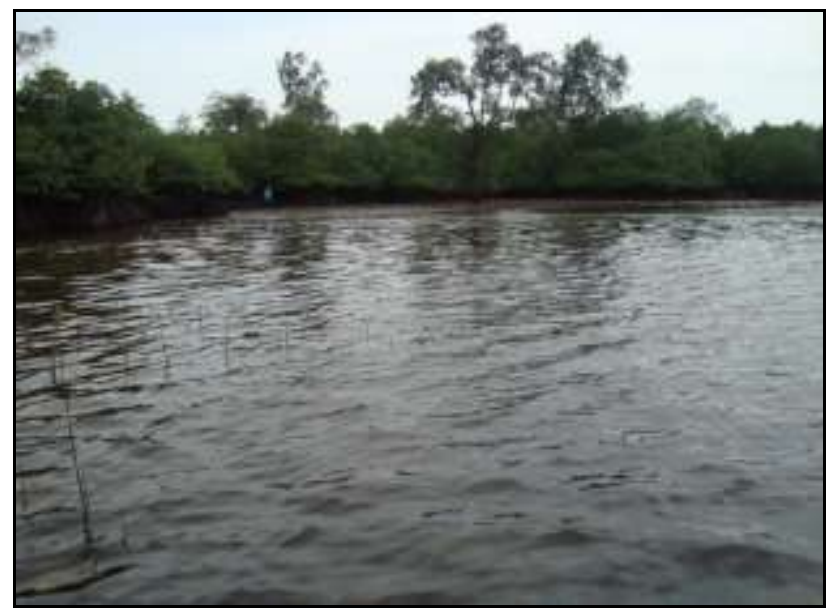

Gambar 4. Kondisi Mangrove Pada Stasiun 3

Jenis -jenis mangrove yang paling mendominasi pada Stasiun 3 untuk kategori semai, belta, dan pohon cenderung sama karena termasuk famili Rhizhoporaceae yaitu jenis $R$. mucronata dan $R$. apiculata. Pada Stadium pertumbuhan pohon ditemukan 3 jenis mangrove yang tumbuh relatif lebih banyak yaitu $R$. apiculata, $R$. mucronata dan $S$. hydrophyllacea dengan indeks nilai penting secara berturut-turut sebesar $144.80 \% \quad(120$ ind/ha), 97.92\% (60 ind/ha), 30.26\% (20 ind/ha). Jenis mangrove $R$. mucronata, $R$. apiculata, dan $S$. hydrophyllacea ditemukan sebagai vegetasi yang tumbuh lebih banyak pada kategori belta dengan indeks nilai penting dan nilai kerapatan tegakan berturut-turut sebesar $123.11 \%$ (3.600 ind/ha), 71.96\% (2.160 ind/ha), 2.66\% (80 ind/ha). Pada stadium pertumbuhan semai ditemukan beberapa jenis mangrove yang sama dengan jenis-jenis mangrove yang ditemukan pada kategori belta dan pohon dimana populasi jenis lebih banyak ditemukan pada Stasiun 3 seperti $R$. mucronata, $S$. hydrophyllacea, dan $R$. apiculata dengan indeks nilai penting dan kerapatan secara berturut-turut sebesar 135.71\% (15.000 ind/ha), 36.43\% (2.000 ind/ha), dan 27,86\% (500 ind/ha). Kerapatan tegakan pohon secara keseluruhan berjumlah $220 \mathrm{ind} / \mathrm{ha}$, kemudian total kerapatan tegakan belta berjumlah 5920 ind/ha dan total kerapatan semai sebesar 17.500 ind/ha.

Di sekitar kawasan Stasiun 3 ditemukan tebangan mangrove yang digunakan untuk jalan perahu nelayan serta bangunan dermaga bahkan ada juga sekelompok jenis mangrove yang mengalami kematian akan tetapi dalam jumlah yang relatif rendah, namun demikian kegiatan ini dampaknya belum mempengaruhi eksistensi mangrove, karena masyarakat setempat saat ini sudah mulai peduli terhadap peran dan manfaat dari hutan mangrove, oleh karena itu kegiatan tersebut harus mendapat perhatian dari 
Pemerintah Daerah setempat agar keberadaan mangrove di pesisir Utara Pulau Mendanau dan sekitarnya tetap terjaga dan lestari.

Pada stasiun 3 jenis $R$. apiculata memilki indeks nilai penting dan kerapatan tertinggi dibandingkan dengan Stasiun 1, dan Stasiun 2, akan tetapi jauh lebih rendah bila dibandingkan dengan Stasiun 4, 5, dan 6, ini berarti bahwa $R$. apiculata memilki peranan yang sangat penting dalam menyusun struktur vegetasi di kawasan tersebut. Hal ini diduga disebabkan karena daya dukung lingkungannya sangat besar untuk perkembangan petumbuhan jenis R.apiculata. dan juga letak stasiun 3 sangat strategis karena berada jauh dari kawasan pemukiman penduduk sehingga terhindar dari pengaruh masukan limbah dari darat dan laut. Pada Stasiun 3 ditemukan jenis $S$. hydrophyllacea dalam jumlah yang rendah, baik untuk kategori semai, belta dan pohon. Noor et al. (1999) juga mengatakan bahwa jenis mangrove $S$. hydrophyllacea merupakan jenis yang langka secara global dan endemik di Indonesia oleh karena itu perlu dilestarikan populasinya.

Komunitas mangrove pada Stasiun 3 saat ini dapat dikatakan tergolong usia generasi muda, hal ini disebabkan karena total keseluruhan kerapatan tegakan pohon lebih rendah dari total keseluruhan kerapatan tegakan populasi belta dan semai, kondisi ini berarti daya regenerasi permudaan pada stadium pertumbuhan pohon sangat baik terlihat adanya kompetisi / persaingan hidup antara pohon,belta dan semai yang terdapat pada Stasiun 3 . Menurut Setyawan (2005), Pohon-pohon yang telah mapan pada umumnya mampu beregenerasi dengan jumlah yang melimpah. Berdasarkan SK Menteri No. 201 Tahun 2004, kondisi mangrove pada Stasiun 3 tergolong baik (bagus) dan dapat tergolong mangrove yang memilki kerapatan lebat, dimana total keseluruhan tegakan pohon ditambahkan dengan tegakan belta berjumlah 6.140 ind/ha.

\section{d. Kondisi Mangrove Pada Stasiun 4}

Stasiun 4 terletak di Tanjung Lumpur Pulau Batu Dinding, Mangrove di sekitar kawasan ini tumbuh lebat dan tersebar secara merata pada beberapa titik pengamatan. komunitas mangrove di wilayah ini berada di daerah terbuka namun tetap terlindung dari hempasan gelombang besar karena daerah tersebut merupakan daerah terumbu karang yang dapat memecah gelombang di pinggir pantai akan tetapi terumbu karang yang berada dibagian terdepan zonasi mangrove banyak yang mengalami kematian akibat terekspos matahari langsung pada saat air surut.

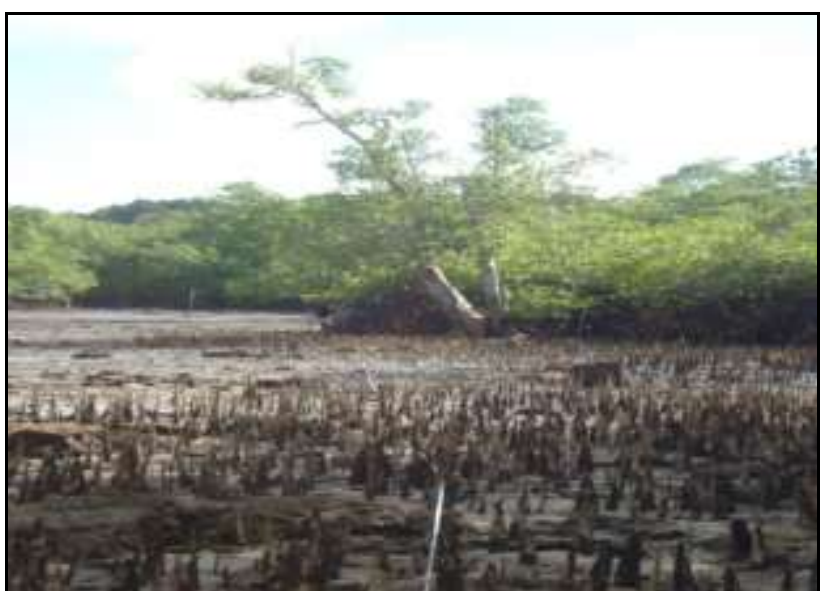

Gambar 5. Kondisi Mangrove Pada Stasiun 4

Pada Stasiun 4 hanya ditemukan 2 jenis mangrove yaitu $S$. alba dan $R$. apiculata dari 2 famili yang berbeda yaitu Rhizophoraceae dan Sonneratiaceae dengan nilai kerapatan tegakan yang sama yaitu sebesar 140 ind/ha akan tetapi indeks nilai pentingnya berbeda. Jenis mangrove $S$. alba kategori pohon merupakan jenis yang memilki populasi lebih banyak pada Stasiun 4 dengan INP sebesar 191,3\%. Hal ini menandakan bahwa S. alba merupakan spesies yang paling berperan penting pada kawasan tersebut dan merupakan spesies yang memilki daya adaptasi yang tinggi dalam menahan hempasan gelombang besar ditambah lagi dengan kondisi ekosistem mangrove di sekitar yang kurang baik dengan kerapatan tajuk jarang.

Pada Stasiun 4 hanya terdapat 1 jenis vegetasi mangrove kategori belta yang ditemukan lebih banyak dibandingkan dengan jenis lainnya yaitu jenis $R$. apiculata dengan INP tertinggi sebesar 200\% (100 ind/ha) hal ini disebabkan karena pada lokasi ini hanya terdapat 1 spesies maka nilai penting mutlak bernilai $200 \%$. Pada tingkat semai, jenis $S$. alba masih menunjukkan nilai penting tertinggi yakni sebesar $129.17 \%$ (2.500 ind/ha), sedangkan INP terendah yaitu dari jenis $R$. apiculata yakni sebesar $70.83 \%$ (1.500 ind/ha).

Total keseluruhan kerapatan tegakan pohon sebesar $280 \mathrm{ind} / \mathrm{ha}$, kemudian total kerapatan tegakan belta sebesar $320 \mathrm{ind} / \mathrm{ha}$ dan total keseluruhan nilai kerapatan tingkat semai pada Stasiun 4 sebesar 4.000 ind/ha, hal ini menandakan bahwa struktur vegetasi mangrove di daerah tersebut tergolong masih muda, hal ini dikarenakan adanya regenerasi yang baik pada tingkat belta dan semai untuk menggantikan mangrove yang berusia tua yang sebagian besar telah mengalami kematian, sehingga dengan melihat total populasi semai yang ada, bisa diramalkan bahwa kondisi mangrove pada masa yang akan datang cukup baik apalagi didukung oleh parameter lingkungan mangrove yang tidak berubah secara dinamis.

Secara umum kerapatan vegetasi strata pohon dan belta pada Stasiun 4 kurang dari 1000 ind/ha. Berdasarkan kriteria yang ditetapkan dalam Keputusan Menteri Negara Lingkungan Hidup RI No. 201 Tahun 2004 tentang kriteria Baku dan Pedoman Penentuan Kerusakan Mangrove, kawasan hutan mangrove pada Stasiun 4 dapat dikategorikan sebagai kawasan hutan mangrove yang mulai terganggu dan mulai mengalami kerusakan. Kerusakan ekosistem mangrove pada Stasiun 4 lebih disebabkan oleh adanya tekanan ekologis yang diduga 
akan semakin tinggi akibat dampak dari kegiatan manusia baik secara langsung maupun secara tidak langsung seperti adanya eksploitasi hutan mangrove yang sering terjadi di Pulau Batu Dinding, Jika eksploitasi berlangsung secara terus menerus maka akan menyebabkan terjadinya kematian dan degradasi hutan mangrove di wilayah sekitar Stasiun 4.

\section{e. Kondisi Mangrove Pada Stasiun 5}

Stasiun 5 terletak di Kampung Seberang Pulau Batu Dinding, daerah ini merupakan daerah yang terlindung karena letaknya yang tersembunyi dan tepat berada di depan Pesisir Utara Pulau Mendanau. Seperti halnya hutan mangrove di Kampung Tomo' Pulau Mendanau dan di daerah sekitar Tanjung Lumpur Pulau Batu Dinding, vegetasi hutan mangrove di Kampong Seberang kawasan Pesisir Selatan Pulau Batu Dinding terlihat tumbuh subur dan memiliki potensi untuk berkembang. karena di sepanjang garis pantai banyak dijumpai semai (seedling) yang tumbuh secara sporadis. Gambaran Kondisi mangrove pada Stasiun 5 disajikan pada Gambar 6 berikut.

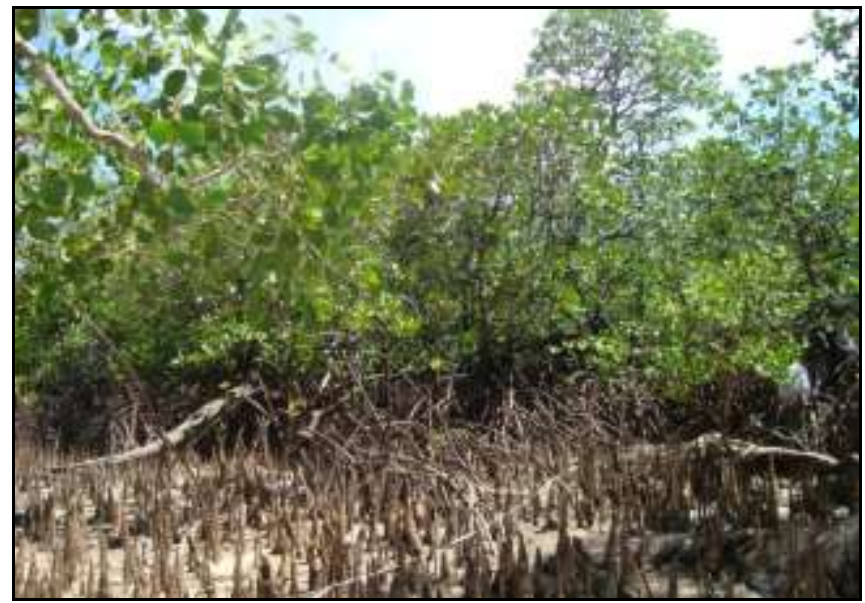

Gambar 6. Kondisi Mangrove Pada Stasiun 5

Hasil analisis yang dilakukan di daerah ini menunjukkan, bahwa secara keseluruhan mangrove di daerah ini memiliki kerapatan yang relatif baik, yakni untuk klasifikasi pohon secara keseluruhan sebesar 580 ind/ha, kemudian belta 320 ind/ha, serta semai (seedling) sebesar 14.500 ind/ha. Pada klasifikasi pohon, jenis vegetasi mangrove yang tumbuh dominan adalah $R$. mucronata, yakni 400 ind/ha, dengan nilai penting sebesar $163.48 \%$ sementara INP terendah pada stasiun 5 yaitu dari jenis $R$. apiculata sebesar $24.6 \%$ dengan nilai kerapatan tegakan terendah sebesar 40 ind/ha. Pada klasifikasi belta (sapling), jenis $R$. apiculata juga menunjukkan nilai kerapatan yang tinggi, yakni sebesar 240 ind/ha (125.17\%) sedangkan nilai kerapatan terendah yaitu jenis $R$. mucronata sebesar 80 ind/ha $(78.83 \%)$. Pada tingkat semai, jenis $R$. mucronata memilki nilai penting tertinggi yakni sebesar $98.02 \%$ (8.500 ind/ha) kemudian diikuti dengan jenis $R$. apiculata dengan INP sebesar $71.03 \%$ (4.500 ind/ha) dan INP terendah untuk kategori semai yaitu dari jenis $S$. alba sebesar 30.34\% (1.500 ind/ha).

Berdasarkan SK Menteri No. 201 Tahun 2004, kondisi mangrove pada Stasiun 5 tergolong baik (bagus) dan dapat tergolong mangrove yang memilki kerapatan lebat dengan pengelompokan usia tua. Hal ini disebabkan karena nilai kerapatan tegakan pohon jauh lebih besar dari pada nilai kerapatan tegakan untuk kategori belta. Setyawan (2006) menyatakan pohon-pohon yang telah mapan pada umumnya mampu beregenerasi dengan jumlah yang melimpah serta Setyawan (2002) menambahkan jika total kerapatan maupun nilai penting untuk kategori belta tidak jauh berbeda dengan pohon diperkirakan kelestarian jenis-jenis pohon akan bertahan dalam waktu yang lama selama kondisi lingkungan tidak mengalami perubahan yang drastis.

\section{f. Kondisi Mangrove Pada Stasiun 6}

Stasiun 6 terletak di daerah pangkalan bakau Pulau Batu Dinding, Stasiun ini terletak dihadapan pesisir utara pulau mendanau dengan hamparan pasir di pesisir pantai, dearah ini sering menjadi tempat berlabuhnya perahuperahu nelayan yang mencari ikan di wilayah sekitar laut Pulau Mendanau dan Pulau Batu Dinding. Gambaran Kondisi mangrove pada Stasiun VI disajikan pada Gambar 7 berikut ini.

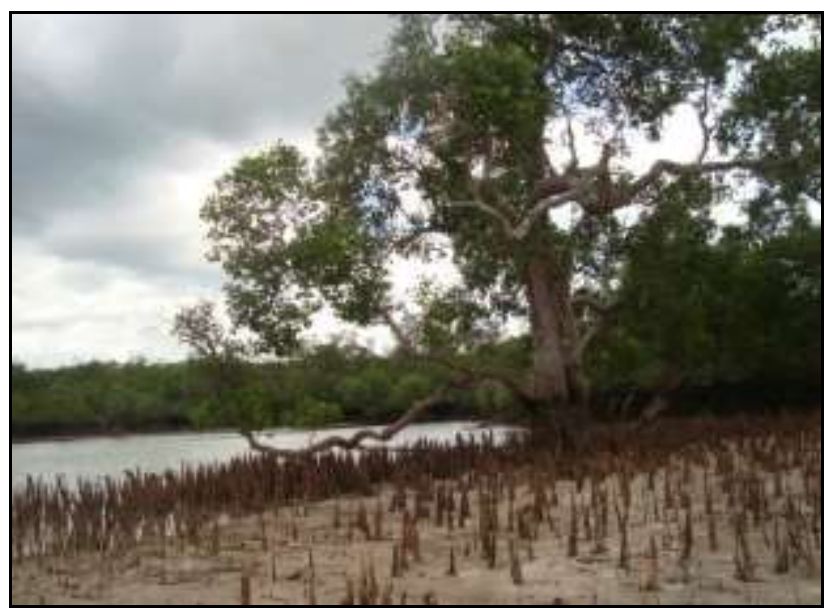

Gambar 7. Kondisi Mangrove Pada Stasiun 6

Pada Stadium pertumbuhan pohon ditemukan jenis mangrove yang tumbuh lebih banyak yaitu $R$. mucronata $R$. apiculata, dan $S$. alba dengan indeks nilai penting secara berturut-turut sebesar $115.08 \%$ (280 ind/ha), $101.54 \%$ (260 ind/ha), 57.61\% (80 ind/ha). Jenis mangrove $R$. apiculata, $R$. mucronata ditemukan sebagai vegetasi yang tumbuh dominan pada kategori belta dengan indeks nilai penting dan kerapatan tegakan berturut-turut sebesar $89.71 \%$ (1.200 ind/ha), 84.65\% (1.200 ind/ha) sedangkan nilai penting terendah terdapat pada jenis $R$. stylosa yakni sebesar $25.65 \%$ (160 ind/ha). Pada stadium pertumbuhan semai ditemukan jenis $R$. apiculata, $R$. mucronata yang mendominasi pada Stasiun VI dengan indeks nilai penting dan kerapatan secara berturut-turut sebesar $86.84 \%$ (7.000 ind/ha), 36.43\% (5.000 ind/ha) sementara populasi jenis yang paling sedikit ditemukan untuk kategori semai pada Stasiun VI yaitu jenis $R$. stylosa dengn INP sebesar 70,17\% (5.000 ind/ha). Kerapatan tegakan pohon secara keseluruhan berjumlah 680 ind/ha, kemudian total kerapatan tegakan belta berjumlah 2.560 ind/ha dan total kerapatan semai sebesar $19.000 \mathrm{ind} / \mathrm{ha}$.

Pada kategori belta dan pohon, jenis $R$. apiculata dan $R$. mucronata merupakan jenis yang tumbuh dominan pada Stasiun VI, Hal ini menandakan bahwa $R$. mucronata merupakan jenis yang paling berperan penting dalam 
penyusunan struktur vegetasi mangrove karena didukung oleh tipe substrat pasir berlumpur cocok untuk kehidupan $R$. apiculata apalagi dari jenis $R$. mucronata. kondisi ini diduga juga karena daerah ini merupakan habitat yang sesuai untuk tumbuh famili Rhizophoraceae pada zonasi mangrove terdepan dengan adaptasi yang tinggi terhadap hempasan gelombang dan salinitas yang tinggi, berdasarkan sampling di lapangan, famili Rhizophoraceae khususnya jenis $R$. mucronata dan $R$. apiculata paling banyak ditemukan sehingga jenis mangrove tersebut tumbuh lebat dan rapat.

Total kerapatan pohon pada Stasiun VI jauh lebih rendah jika dibandingkan dengan total kerapatan belta, kondisi ini diduga penyebabnya adalah tingginya tegakan untuk klasifikasi belta $R$. apiculata, R. mucronata sudah hampir mencapai sekitar 20 meter, perakaran mangrove yang sangat rapat, serta kanopi tutupan tajuknya yang relatif tinggi, sehingga terjadi kompetisi dalam memperoleh ruang untuk mempertahankan hidup dan berkembang. Sementara pada kategori semai, kembali jenis $R$. apiculata menjadi jenis yang dominan Hal ini mencerminkan bahwa kompetisi dalam memperoleh sinar matahari untuk melakukan proses fotosintesa adalah sangat tinggi, sehingga jumlah semai jenis ini relatif rendah.

Jika melihat perbandingan jumlah kerapatan pohon, belta, dan semai antar stasiun pengamatan di dua lokasi penelitian dapat dikatakan bahwa pada stasiun I, dan II di pesisir Utara Pulau Mendanau dan pada stasiun IV di Pulau Batu Dinding perlu dijadikan kawasan konservasi atau pusat rehabilitasi, hal ini dikarenakan daerah-daerah tersebut kurang memilki persediaan semai (seedling) sehingga diperlukan suatu perlindungan untuk melindungi vegetasi yang ada. Sementara dari perbandingan antara pohon, belta dan semai pada Stasiun III, V dan VI. maka daerah ini dirasa cocok untuk menjadi daerah pembibitan. Tingginya kerapatan pada kategori semai ini didukung oleh kondisi substrat yang kaya bahan organik, gelombang yang agak tenang dan faktor-faktor lingkungan lain yang sesuai untuk tumbuhnya semai di daerah tersebut.

\section{Indeks Keanekaragaman (H'), Keseragaman (E) \& Dominansi (C)}

Indeks Keanekaragaman merupakan salah satu indeks ekologi yang biasa digunakan dalam mengevaluasi kondisi suatu ekosistem berdasarkan indikator biologi. Hasil Perhitungan Indeks keanekaragaman, indeks keseragaman dan indeks dominansi jenis mangrove pada stadium pertumbuhan pohon disajikan pada Tabel 5 dibawah ini:

Tabel 5. Indeks Keanekaragaman (H'), Keseragaman (E) dan Dominansi (C)

\begin{tabular}{cccc}
\hline Stasiun & \multicolumn{3}{c}{ Indeks Ekologi } \\
\cline { 2 - 4 } & $\mathrm{H}^{\prime}$ & $\mathrm{E}$ & $\mathrm{C}$ \\
\hline 1 & $\mathbf{0 . 9 1 2}$ & 0.912 & $\mathbf{0 . 1 3 7}$ \\
2 & 0.497 & 0.825 & 0.361 \\
3 & 0.317 & $\mathbf{0 . 6 1 7}$ & $\mathbf{0 . 5 0 5}$ \\
4 & $\mathbf{0 . 2 9 9}$ & $\mathbf{0 . 9 9 5}$ & 0.502 \\
5 & 0.415 & 0.870 & 0.435 \\
6 & 0.493 & 0.819 & 0.356
\end{tabular}

Indeks keanekaragaman jenis pada 6 Stasiun pengamatan berkisar antara $0.299-0.912$, menurut Wlham dan Dorris (1986) dalam Odum (1993) apabila klasifikasi indeks keanekaragaman Shannon-Wienner H' < 1 maka keanekaragaman jenis pada seluruh stasiun pengamatan dikategorikan rendah, kondisi ini diduga karena adanya tekanan ekologis yang tinggi serta pengambilan sampel hanya sebatas $100 \mathrm{~m}$ sehingga zonasi dan kenekaragaman jenis yang ditemukan sangat rendah. Indeks keseragaman berkisar antara $0.617-0.912$, menurut Krebs (1989) dalam Odum (1993), apabila E > 0.6 maka keseragaman spesies tinggi artinya sebaran individu setiap spesies hampir merata dan seragam pada seluruh stasiun pengamatan. Indeks dominansi seluruh stasiun pengamatan berkisar antara $0.137-0.502$, menurut Simpson (1949) dalam Odum (1993) pengelompokan indeks dominansi $(0<\mathrm{C}<0.5)$ menunjukkan tidak ada individu yang paling mendominasi pada seluruh stasiun pengamatan karena jenis-jenis mangrove yang ditemukan cenderung seragam.

\section{KESIMPULAN DAN SARAN}

Dari penelitian yang telah dilakukan, maka dapat ditarik beberapa kesimpulan, yaitu: 1) Jenis mangrove yang ditemukan di pesisir utara Pulau Mendanau dan Pulau Batu Dinding adalah 8 jenis mangrove sejati dari 5 famili yang teridentifikasi di keseluruhan stasiun pengamatan, meliputi Rhizophoraceae ( $R$. apiculata, $R$. mucronata, $R$. stylosa, B. gymnorrhiza), Sonneratiaceae $(S$. alba), Meliaceae ( $X$. granatum), Combretaceae ( $L$. littorea), Rubiaceae ( $S$. hydrophyllaceae). Disamping itu ada juga ditemukan 4 jenis mangrove asosiasi dari 4 famili, yaitu Malvaceae (H. tiliaceus), Convolvulaceae (I. pescaprae), Pandanaceae (Pandanus sp.), Goodeniaceae ( $S$. tacada). Adapun jenis mangrove yang paling mendominasi, yaitu Rhizopora apiculata, Rhizophora mucronata, dan Sonneratia alba. 2) Kondisi Mangrove diarea studi masih tergolong bagus (rapat), pada daerah kelas mangrove belum terlihat adanya peralihan peruntukkan menjadi pertambakan atau pun pemukiman. Pada daerah yang mengalami pengkonversian banyak ditemukan mangrove genus Rhizophora spp.

\section{DAFTAR PUSTAKA}

Arief, A. 2003. Hutan Mangrove. Cetakan pertama. Yogyakarta: Kanisius (Anggota IKAPI).

Bengen, D. G. 1999. Pedoman Teknis Pengenalan dan Pengelolaan Ekosistem Mangrove.

Bengen, D. G. 2002. Sinopsis Ekosistem dan Sumberdaya Alam Pesisir dan Laut serta Prinsip Pengelolaannya. Pusat Kajian Sumberdaya Pesisir dan Lautan IPB: Bogor. 63 hal.

Brower J. E. dan J. H. Zar. 1989. Field and Laboratory Methods for General Ecology. W. M. Brown Company Publ. Dubuque Lowa. 
Dahuri, R., J. Rais, S. Putra Ginting dan M.J. Sitepu. 2008. Pengelolaan Sumberdaya Wilayah Pesisir dan Lautan Secara Terpadu. P.T.Pradnya Paramita: Jakarta. 305 hal.

Effendi H. 2003. Telaah Kualitas Air. Yogyakarta: Kanisius.

Fachrul M F. 2006. Metode Sampling Bioekologi. Jakarta: PT. Bumi Aksara.

Kepmen LH No. 201. 2004. Kriteria Baku dan Pedoman Penentuan Kerusakan Mangrove. Deputi MENLH. Jakarta. 10 halaman.

Kitamura S, C. Anwar, A. Chaniago, and S. Baba. 1997. Handbook of Mangrove in Indonesia: Bali and Lombok. Denpasar : JICA/ISME. The Development of Sustainable Mangrove Management Project.

Kusmana C. 1997. Metode Survey Vegetasi. Bogor: PT. Penerbit Institut Pertanian Bogor.

Marinda A. 2006. Struktur Komunitas dan Zonasi Mangrove di Perairan Teluk Gilimanuk Taman Nasional Bali Barat Provinsi Bali. Skripsi (tidak dipublikasikan).

Noor Y R, Khazali, Suryadiputra IN. 1999. Panduan Pengenalan Mangrove di Indonesia Bogor: Wetlands International. 220 hal.

Nontji A. 1993. Laut Nusantara. Cetakan ke-2. Jakarta: Djambatan. 357 hal.

Odum, E. P. 1993. Dasar-Dasar Ekologi. Gadjah Mada University Press. Yogyakarta.

Onrizal, 2007. Pengenalan Vegetasi Mangrove. Departemen Kehutanan. Universitas Sumatera Utara.

Saparinto C. 2007. Pendayagunaan Ekosistem Mangrove. Edisi Pertama, Cetakan kesatu. Semarang: Dahara Prize. 236 hal.

Setyawan A. D, A. Susilowati dan Sutarno. 2002 Biodiversitas Genetik, Spesies dan Ekosistem Mangrove di Jawa. Cetakan pertama. Surakarta: Kelompok Kerja Biodiversitas Jurusan Biologi Fakultas Matematika dan Ilmu Pengetahuan Alam, Universitas Sebelas Maret.

Setyawan A D. 2008. Biodiversitas Ekosistem Mangrove di Jawa; Tinjauan Pesisir Utara dan Selatan Jawa Tengah (Kumpulan Jurnal). Surakarta: Jurusan Biologi FMIPA Universitas Sebelas Maret (UNS).

Setyawan A. D. 2006. Permasalahan Konservasi Ekosistem Mangrove di Pesisir Kabupaten Rembang Jawa Tengah. Jurnal Biodiversitas 7(2). Hal. 159-163.
Supriharyono. 2000. Pelestarian dan Pengelolaan Sumberdaya Alam di Wilayah Pesisir Tropis. Jakarta: PT Gramedia Pustaka Utama. 